\title{
Effects of Aqueous Shoot Extract of Tithonia diversifolia on the Growth of Seedlings of Monodora tenuifolia (Benth.), Dialium guineense (Willd.) and Hildegardia barteri (Mast.) Kosterm
}

\author{
Samson Olajide OKE, Abisola Victoria AWOWOYIN, Shaid \\ Remi OSENI, Emmanuel Lekan ADEDIWURA
}

Obafemi Awolowo University, Department of Botany, Ile-ife, 220005, Nigeria; soke@oauife.edu.ng (corresponding author)

\begin{abstract}
The allelopathic effects of fresh shoot aqueous extract of Tithonia diversifolia (Hemsl.) A.Gray, an invasive species introduced into Africa from North and Central America, on the growth of seedlings of three woody species: Monodora tenuifolia, Dialium guineense and Hildegardia barteri were investigated. The fresh shoot aqueous extract of Tithonia diversifolia was applied to the established seedlings of the three woody species over a period of ten weeks. The fresh shoot aqueous extract of Tithonia diversifolia had a significant effect (inhibitory and stimulatory) on growth parameters such as shoot height, leaf area, number of leaves and chlorophyll content of the three woody species.The study revealed that the fresh shoot aqueous extract of Tithonia diversofolia have different effects (inhibitory and stimulatory) on the seedlings and the mode of action depends on the associated woody plant species.
\end{abstract}

Keywords: allelopathy, Dialium guineense, fresh shoot aqueous extract, Hildegardia barteri, Monodora tenuifolia, Tithonia diversifolia

\section{Introduction}

The two species of the genus Tithonia, Tithonia diversifolia and Tithonia rotundifolia are native to North and Central America from where they have been introduced to Africa. They belong to the tribe Heliatheae and the family Asteraceae. This family is one of the most contributive families to the naturalized flora in Nigeria, as well as the most notorious contributors to the naturalized flora of the world (Wu and Wang, 2005). The family Asteraceae contains about 1620 genera; it is a very large cosmopolitan family with trees, vines, shrubs and herbs. They are distributed throughout the world, and are most common in the arid and semi-arid regions of subtropical and lower temperate latitudes (Barkley et al., 2006).

In Africa, 11 species of the genus Tithonia have been introduced (Akobundu and Agyakwa, 1987); these two species of the genus have become invasive species in Africa. They have become naturalized in Southern Africa, while Tithonia diversifolia was naturalized in West Africa (Moughalu and Chuba, 2005). In these areas, the species have established themselves as serious weeds of arable crop, plantations, abandoned lawns and roadsides. They are aggressive colonizers of new sites, colonizing every available sunny space with highwater table. They are alloptric, never found growing in mixed population. Opinions vary as regards to their introduction and subsequent establishment. In West Africa, Tithornia diversifolia has been reported to be introduced as an ornamental plant (Akobundu and Agyakwa, 1987) and with imported grains (Lordbanjou, 1991).
In Nigeria, especially in the lowland rainforest, as well as in other habitats, exotic plant species have dominated a sizeable portion of the secondary fallow vegetation (Imeokpara and Okusanya, 1994). Most farmers find it difficult to manage Tithonia sp. infestation in their farmlands, because the plant exhibit what is known as allelopathy (Imeokpara and Okusanya, 1994). Introduction of plant species, especially the invasive ones, into a new environment, deliberately or otherwise, may result into a cascade of unexpected ecological effects (Howard et al., 2000). It has been reported that naturalized or invasive species may influence other species through competition, altered ecosystem processes or through other pathway such as allelopathy or phytotoxicity (Samuel et al., 2005).

Allelopathy is known to include both harmful and beneficial biochemical interactions between all types of plants, including microorganisms (Rice, 1984). Therefore, allelopathy has been described as the inhibitory or stimulatory effect of a plant (donor) on another plant (receiver) through the chemicals released from the donor plant to the environment, mostly in the soil (Taiwo and Makinde, 2005). Samuel et al. (2005) have reported that invasive species succeed over the native species through the mechanism of allelopathy. Extract from parts of certain invasive species such as Lolium arundinaceam (tall fescue) and Elaeagnus umbellata (autum olive) affected seedlings emergence time and leaf biomass of native tree seedling in varying degrees in North America (Samuel et al., 2005). Tongma et al. (1998) reported that T. diversifolia contains some allelochemicals and they suggested that the plant is capable of posing a serious threat of phytotoxicity to ag- 
ricultural crops. In addition, extracts from Tithonia species have shown to cause retardation in germination and growth parameters as well as fresh and dry matter production in Amaranthus cruentus; these retardations were shown to be pronounced in older plants (Otusanya et al., 2007). They further suggested that the degree of retardation of the aqueous extract from fresh shoot was greater than the dry shoot aqueous extract.

Many works on Tithonia species extracts have shown that it can be either beneficial or harmful to crop plants or weeds. The dual role of allelopathic substances on the growth parameters of woody plant species have not been fully investigated. Hence, the present study aims to investigate the effects of the fresh shoot aqueous extract of $T i$ thonia diversifolia on the growth of the seedlings of three woody plant species namely Monodora tenuifolia, Dialium guineense and Hildegardia barteri.

\section{Materials and methods}

\section{Collection of plant materials}

This study was carried out at the screen house of the Botany Department, Obafemi Awolowo University, IleIfe, Nigeria, between January and July 2007. The plant materials used include fresh shoot of Tithonia diversifolia and seedlings of Monodora tenuifolia Benth., Dialium guineense Willd. and Hildegardia barteri (Mast.) Kosterm. The fresh shoot of Tithonia diversifolia were collected from a research field containing $T$. diversifolia beside the screen house. The seedlings of the of D. guineense and H. barteri were collected from the Forestry Research Institute of Nigeria (FRIN), Ibadan, Nigeria, while the seedlings of $M$. tenuifolia and the top soil used for the study were collected from the reforestation project site of the Department of Botany, Obafemi Awolowo University, Ile-Ife, Nigeria.

\section{Seedlings establishment and treatments}

The seedlings of the three woody plant species were transplanted into pots filled with topsoil. Twenty pots, perforated at the base (to allow drainage and prevent water logging) were set up for each species. The seedlings were left in a shaded area for about two months to allow them to acclimatize and survive the transplanting procedure. They were thereafter exposed to sunlight and adequate watering of the plants was done in order to establish them. Within the first two months, the shoot height, leaf area and leaf number of each plant were recorded weekly. Plants that showed symptoms of weakness were removed and replaced during this period. The pots with properly labelled plants were later moved into the screen house of the Department of Botany, Obafemi Awolowo University,Ile-Ife, Nigeria. Extract from the fresh shoot of Tithonia diversifolia was prepared using the methods of Ahn and Chung (2000) and that of Samuel et al. (2005). After the successful establishment of the plants into their new environment, each species was randomly divided into two groups. Fifteen pots were set aside for the experimental treatments with aqueous extracts from Tithonia diversifolia, while the remaining five served as control. $200 \mathrm{ml}$ of the shoot extract were added to the individual seedlings every other day for about three months, while $200 \mathrm{ml}$ of water were added to the control plants.

\section{Data collection and analysis}

Physical plant parameters such as plant shoot height, leaf length, leaf breadth with the latter two parameters used to calculate the Leaf Area (LA) using the formula of Hoyt and Bradfield (1962) were measured. All measurements were done in replicates and the means were calculated. Determination of the chlorophyll content was carried out using the method of Comb et al. (1985). Chlorophylls 'a' and 'b' and total chlorophyll contents were calculated as follows:

Chlorophyll 'a' $(\mu \mathrm{m})=13.19$ A664 - 2.57A647;

Chlorophyll 'b' $(\mu \mathrm{m})=22.10 \mathrm{~A} 647-5.26 \mathrm{~A} 664$;

Total chlorophyll $(\mu \mathrm{m})=7.93 \mathrm{~A} 664+19.53 \mathrm{~A} 647$ or

Chlorophyll 'a' + chlorophyll 'b'. A664 = absorbance at $664(\mu \mathrm{m})$ wavelength; A647 = absorbance at $647(\mu \mathrm{m})$ wavelength.

The data obtained were subjected to Analysis of Variance using the software SAS Release 8.1. Significant means were separated by Duncan's multiple range test at the 5\% probability level.

\section{Results}

Growth characteristics during the period of the seedlings establishment, before the application of the extract

The three woody species seedlings revealed a steady increase in the mean shoot height, mean leaf number and mean leaf area throughout the period of seedlings establishment, before the application of Tithonia extract. It was observed that $H$. barteri had the highest mean shoot height and mean leaf area, while D. guineense had the highest mean leaf number, lowest mean shoot height and mean leaf area. Monodora tenuifolia had the intermidiate shoot height, mean leaf number and mean leaf area (Fig.1). The analysis of variance for the seedlings growth parameters that were measured during the growing period, before extract application, revealed that $H$. barteri had a significantly higher mean shoot height and mean leaf area $(\mathrm{p}<0.05)$ than $M$. tenuifolia and D. guineense, while D. guineense had a significantly higher mean leaf number $(\mathrm{p}<0.05)$ than $H$. barteri and Monodora tenuifolia (Tab. 1).

\section{Growth characteristics of the seedlings during the period of extract application}

The results of the measured three physical parameters of the three woody species during the application of the extract, weeks after establishment (WAE), revealed a steady increase in the mean shoot height, mean leaf number and mean leaf area throughout the period (ten weeks) 


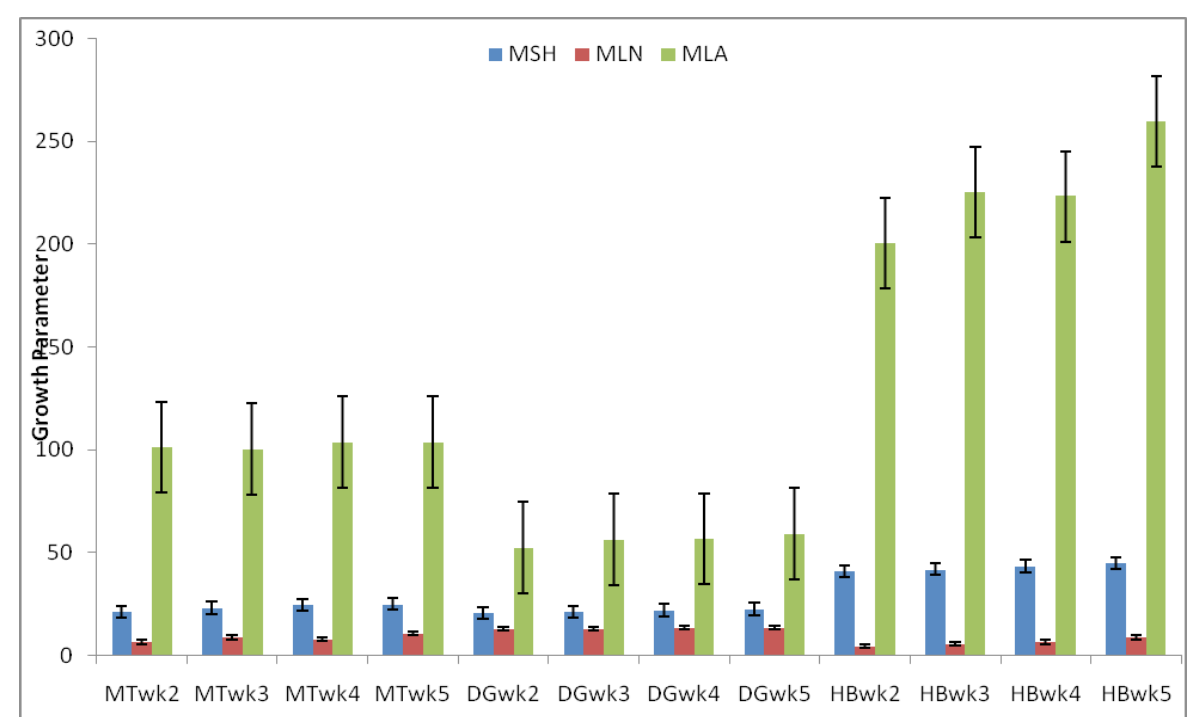

Week before application of extract

Fig. 1. Growth characteristics of the three woody species during the period of the seedlings establishment, before the application of the extract

of extract and water applications. In the extract application regime, the mean shoot height and mean leaf area of $H$. barteri is significantly higher than those of $M$. tenuifolia and $D$. guineense, while its mean leaf number is significantly lower. In the water application regime, which is the control, all the three measured physical parameters of H.barteri were significatly higher than that of $M$. tenuifolia and D. guineense (Tab. 2). The growth rate in H. barteri and $M$. tenuifolia was very sharp and a consistent trend was observed in both treatment regimes, whereas $D$. guineense maintained a slow increase throughout the growing period. Comparison of the response of the seedlings of the three woody species to extract and water application regimes revealed that the plants grown in the extract regime had higher mean shoot height and higher mean leaf area in $H$. barteri and M. tenuifolia than those grown in the

Tab. 1. Response of the three woody species seedlings during the period of the seedling establishment before the application of the aqueous extract

\begin{tabular}{cccc}
\hline & MSH & MLN & MLA \\
\hline H. barteri & $42.84 \mathrm{a}$ & $6.45 \mathrm{~b}$ & $227.09 \mathrm{a}$ \\
M. tenuifolia & $23.49 \mathrm{~b}$ & $8.55 \mathrm{~b}$ & $102.33 \mathrm{~b}$ \\
D. guineense & $21.66 \mathrm{~b}$ & $13.30 \mathrm{a}$ & $56.27 \mathrm{c}$ \\
\hline
\end{tabular}

Means in each column with the same letter are not significantly different at $\mathrm{p}<0.05$

Tab. 2. Response of the three woody species seedlings during the period of aqueous extract application

\begin{tabular}{ccccccc}
\hline & \multicolumn{3}{c}{ Water regime } & \multicolumn{3}{c}{ Extract regime } \\
\hline Species & MSH & MLN & MLA & MSH & MLN & MLA \\
\hline H. barteri & $51.08 \mathrm{a}$ & $9.90 \mathrm{a}$ & $299.36 \mathrm{a}$ & $61.45 \mathrm{a}$ & $13.79 \mathrm{~b}$ & $400.22 \mathrm{a}$ \\
M. tenuifolia & $28.13 \mathrm{~b}$ & $6.43 \mathrm{~b}$ & $114.92 \mathrm{~b}$ & $36.50 \mathrm{~b}$ & $16.47 \mathrm{a}$ & $153.56 \mathrm{~b}$ \\
D. guineense & $28.77 \mathrm{~b}$ & $9.10 \mathrm{a}$ & $72.42 \mathrm{~b}$ & $24.79 \mathrm{c}$ & $19.41 \mathrm{a}$ & $57.31 \mathrm{c}$ \\
\hline Means in each column with the same letter are not significantly different at $\mathrm{p}<0.05$ \\
MSH- mean shoot height, MLN- mean leaf number and MLA- mean leaf area
\end{tabular}

water regime. The seedlings of all the three woody species had higher values for mean leaf number in the extract regime than the water regime. D. guineense had higher mean shoot height and higher leaf area in the water regime than in the extract regime. (Fig. 2a, b, c). The t-test showed that the seedlings in the extract regime had significantly higher values for the measured physical parameters than in water regime.

The results of the chlorophyll content of the seedlings of the three woody species in the extract and water application regimes revealed a decline in their chlorophyll content as the growth period progresses in the extract regime, while it was not the same in the water regime (Fig.3a, b, c). The rate of decline was the most for $D$. guineense, least in $H$. barteri and intermediate in $M$. tenuifolia. The t-test showed that the seedlings in the extract regime had significantly lower values for the chlorophyll than in water regime.

\section{Discussion}

The effects of fresh shoot aqueous extract of Tithonia diversifolia on the growth characteristics of the selected three woody species: $M$. tenuifolia, D. guineense and $H$. barteri were investigated in this study. The choice of growth parameters of young seedling was due to the fact that known sites of action for some allelochemicals have been reported to include cell division, pollen germination, nutrient uptake, photosynthesis and specific enzyme function, with commonly cited effects being reduced on seed germination and seedling growth (Ferguson and Rathinasabapath, 2009). The results clearly showed that Tithonia diversifolia aqueous shoot extract is an important factor in the growth of these woody species. Studies carried out in the past on allelopathy activity of Tithonia diversifolia have revealed that it could affect the growth and development 


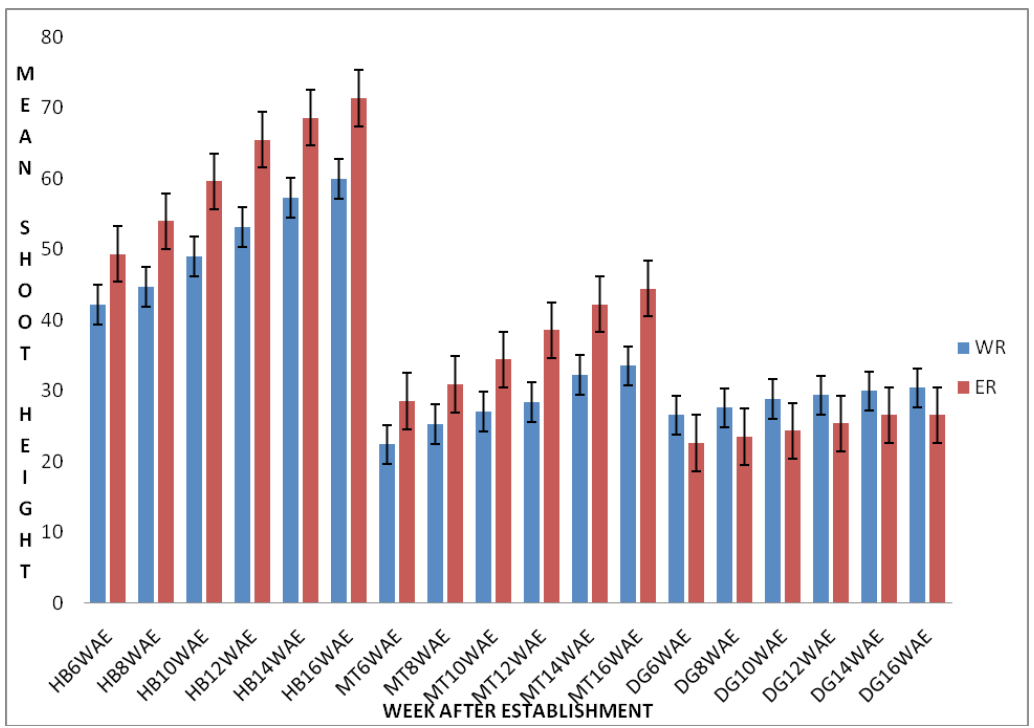

Fig. 2a. Response of mean shoot height of the three woody species to water and extract regimes during growing period after establishment

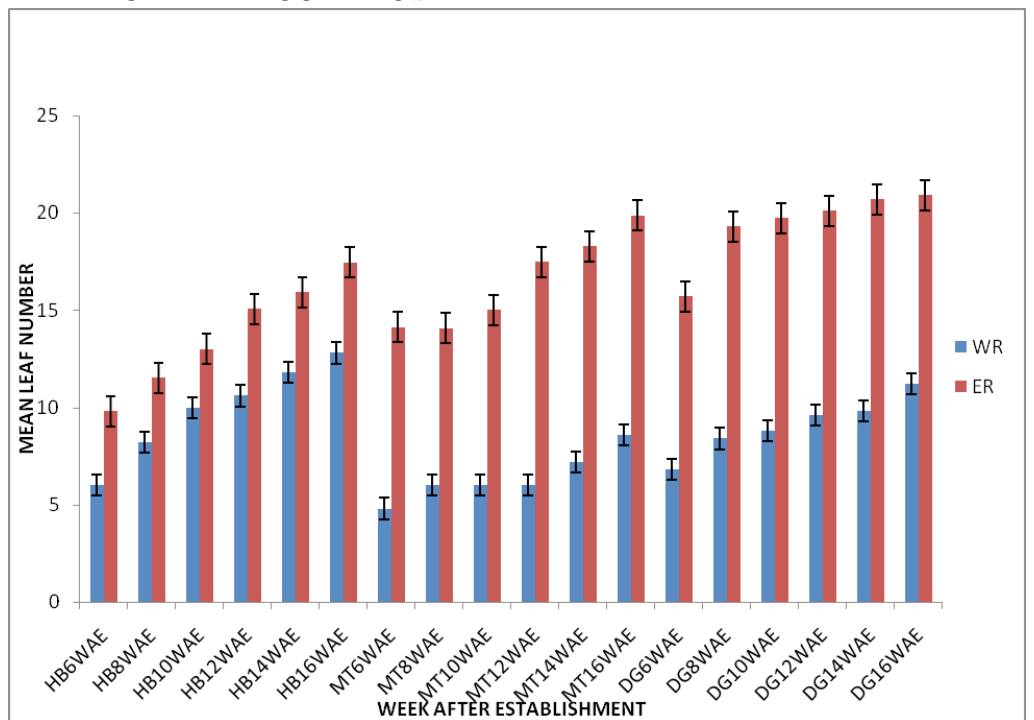

Fig. 2b. Response of mean leaf number of the three woody species to water and extract regimes during growing period after establishment

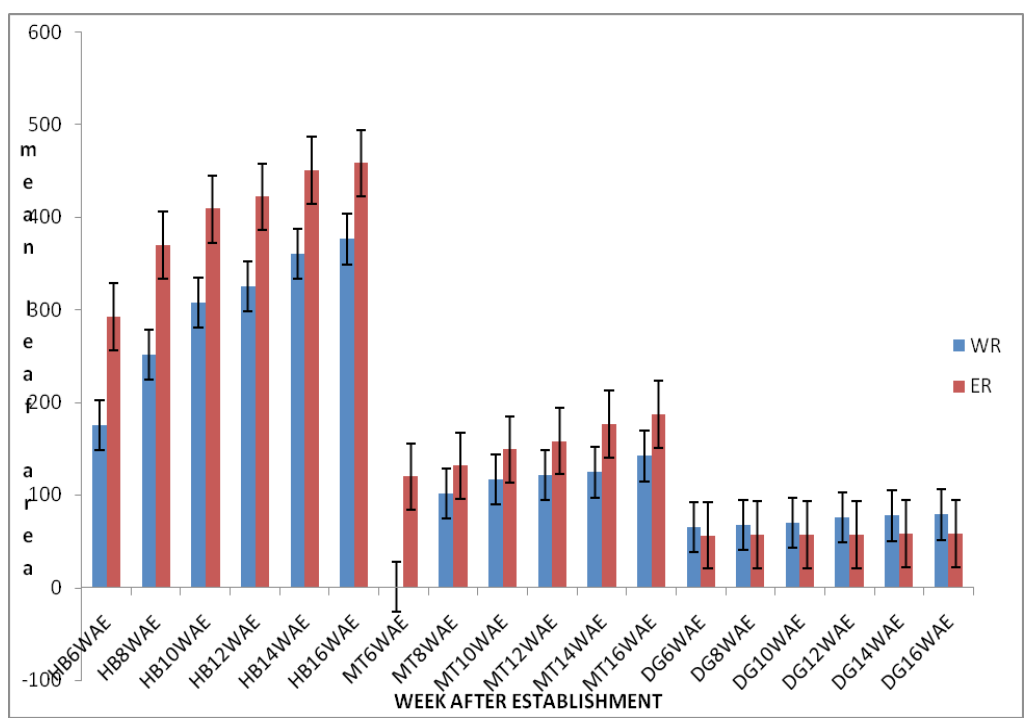

Fig. 2c. Response of mean leaf area of the three woody species to water and extract regimes during the growing period after establishment 


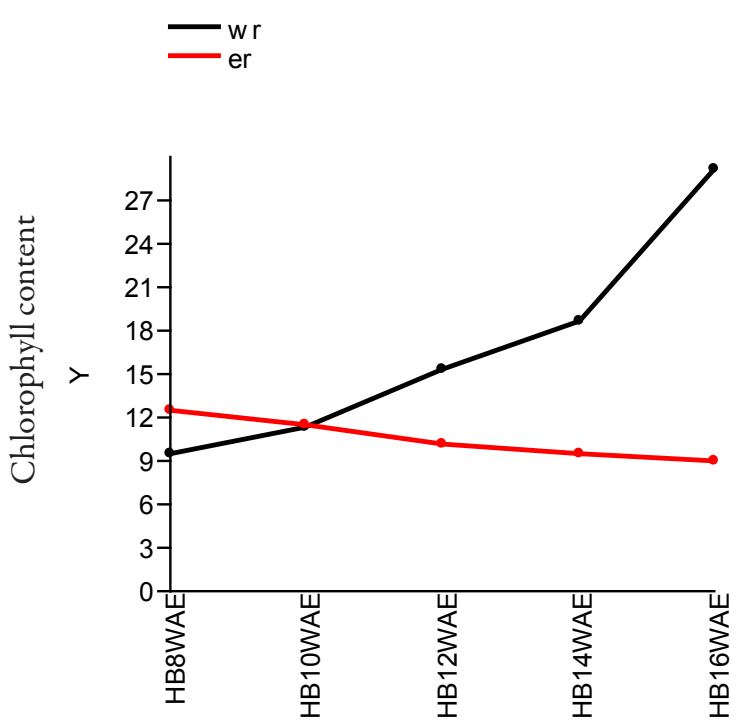

Week after establishment

Fig. 3a. Chlorophyll content of Hildegardia barteri in water and extract regimes

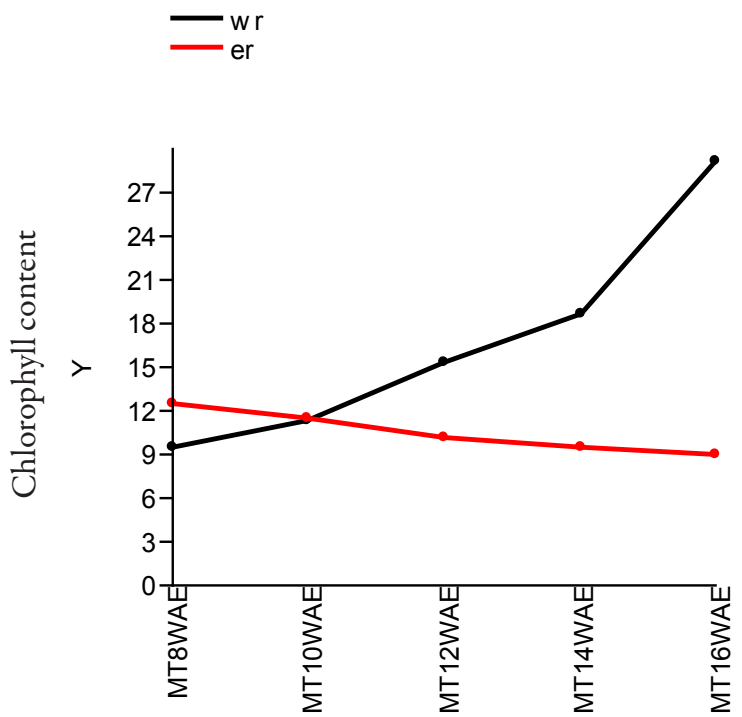

Week after establishment

Fig. 3b. Chlorophyll content of Monodora tenuifolia in water and extract regimes

of other plants, including the growth of several crops (Oyerinde et al., 2009), and most times, it completely suppress other plants that share the same habitat (Liu and Lovett, 1993). The allelopathic interactions between plants have been implicated in the patterning of vegetation and weed growth in agricultural systems (Rice, 1984).

The results of the experiments show that the extract of Tithonia diversifolia could either have inhibitory effect or promote the growth of the seedlings of the three selected woody species. The results clearly show that the extract promoted the shoot height, leaf number and leaf area in

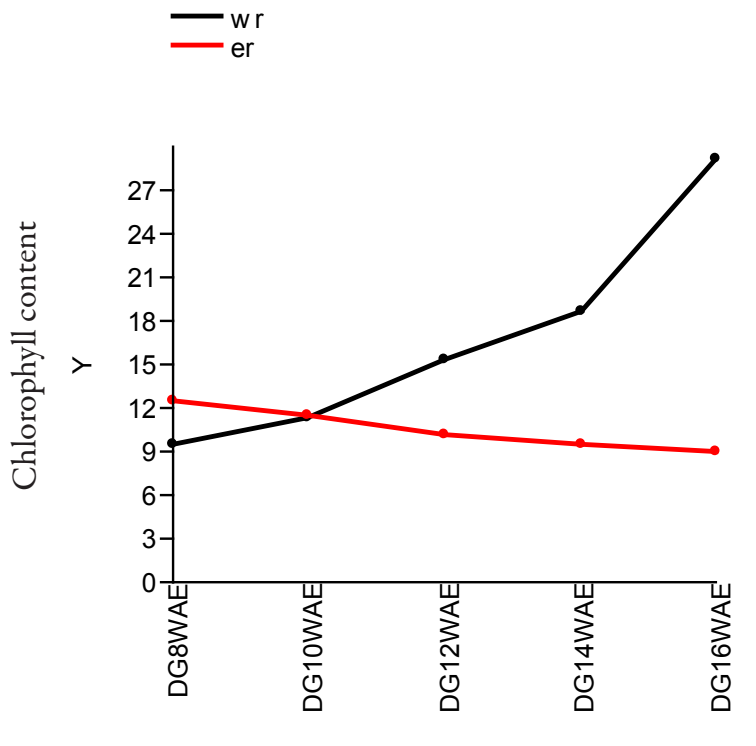

Week after establishment

Fig. 3c. Chlorophyll content of Dialium guineense in water and extract regimes

M. tenuifolia and $H$. barteri, but it was inhibitory in $D$. guineense. This is in agreement with the findings of Nassir et al. (2005) on the stimulatory effect of Stevia rebaundiana on lettuce and cucumber, and with the work of Mo et al. (2004) where they reported that aqueous extract from Lactarius hatsudake had stimulatory effect on the growth of rice. Taiwo and Makinde (2005) have equally reported similar effects when Vigna unguiculata was treated with extract from Tithonia sp.

The plant characteristics that were examined in this study revealed that each plant had its own response to the extract regime during its growth; however, a general pattern could be established. This study shows that the mean shoot height of $M$. tenuifolia and $H$. barteri seedlings were higher in the extract regime than in water, even though it was more pronounced in $H$. barteri. It shows that the growth of these two woody seedlings, except for D. guineense, was not inhibited by the allelochemicals that are present in the fresh shoot extract of Tithonia diversifolia species. Inhibitions of germination and growth by some members of Asteraceae family in several plants have been reported (Analuisa and Silvia, 1978), and Otusanya et. al. (2007) who noted that growth parameters of Amaranthus cruentus have been inhibited by aqueous extract of $T$. diversifolia. Similarly, Baruah et al. (1994) have reported inhibition of some crops by Tithonia diversifolia. These reports support the observed inhibition of growth found in $D$. guineense and contradict the present observations with the other two woody species.

The leaf area results show that in the extract regime, the leaf area of the seedlings was higher than in those of seedlings in water regime, except again for D. guineense, where that of water regime was a little more than that of 
the extract regime. The observation with $D$. guineense is found to be consistent with the findings of Patterson (1981), who reported that applications of some synthetic allelochemicals reduce the leaf area of soybean. Einhellig et al. (1982) stated that allelochemicals must be present at a level above threshold concentration for the impact to be seen. This perhaps was the case with the seedlings of $M$. tenuifolia and $H$. barteri, where lower concentration of the extract may have enhanced the leaf area rather than inhibiting them. In addition, seedlings grown in extract regime were shown to have an increase in the mean number of leaf as compared to those grown in water regime.

The results equally show that chlorophyll content of the seedlings grown in water regime were higher than those grown in extract regimes; the extract greatly reduce the chlorophyll contents of the seedlings grown in it. It shows that the extract of Tithonia diversifolia reduced the chlorophyll contents of the plant grown in it, and the effect is much more with the seedlings of $D$. guineense than for the other two species. Similar results have been observed where extract from allelopathic plants have been shown to impair chlorophyll synthesis or reduce chlorophyll content in plants (Colton and Einhellig, 1980; Alsaadwi, 1992; Otusanya et al., 2007). The reduction in chlorophyll content would definitely results in impaired or reduced photosynthesis, thereby leading to a reduction in growth of the affected plants (Yang et al., 2002). This appears to be the reason why the shoot height in $D$. guineense is greatly reduced as compared to the other two species.

In general, the results revealed that $H$. barteri seedlings responded more positively than the other two species to the extract. This might be because $H$. barteri is a tree with soft wood while the other two species are hard wood. The response of $D$. guineense might equally be because it is a hard wood with dense leaf crown.

In conclusion, this study has shown that the effect of Tithonia diversifolia shoot extracts on the three woody species seedling was pronounced. It reinforces the importance of Tithonia diversifolia as an allelopathic plant which gives either stimulatory or inhibitory interaction with other plant species. We therefore suggest that Tithonia diversifolia could be used as an allelopathic plant, which can be employed to achieve an increase in the seedling of some woody species.

\section{References}

Ahn JK, Chung M (2000). Allelopathic potential of rice hulls on germination and seedling growth of Barnyeard grass. Agronomy Journal 92:1162-1167.

Akobundu IO, Agyakwa GW (1987). A handbook of West Africa weeds. International Institute of Tropical Agriculture, Ibadan, Nigeria.

Alsaadwi LS (1992). Allelopathic research activity in Iraq. In Allelopathy: Basic and applied effect of Vulpia residues. Journal of Experimental Agriculture 37(6):647-660.
Ana L, Silvia D (1978). Allelopathic potential of Ambrosia cumanensis in tropical zone of Mexico. Journal of Chemical Ecology 4(3):289-307.

BarkleyTM, Brouillet L, Strother JL (2006). Flora of North America-Asteraceae, p. 297-299. In: Baillargeon G and Editorial Committee of the Flora of North America. Oxford University Press, New York, USA.

Baruah NC, Sarma JC, Barua NC, Sarma S, Sharma RP (1994). Germination and growth inhibitory sesquiterpene, lactones and flavone from Tithonia diversifolia. Phytochemistry 36:29-36.

Comb JI, Long SI, Scurlock J (1985). Techniques in bioproductivity and photosynthesis. Pergamon Press, Oxford, New York, Toronto, Sydney, Frankfurt.

Colton CE, Einhellig FA (1980). Allelopathic mechanisam of velvetleaf (Abuttlon theophrasti) Medic. Malvaceae on soybean. American Journal of Botany 67:1407-1413.

Einhellig FA, Schon,MK, Rasmussen JA (1982) Factors affecting effectiveness of allelochemicals. Journal of Plant Growth Regulation 1:125-158.

Ferguson JJ, Rathinasabapathi B (2009).Allelopathy :How plants supress other plants. University of Florida IFAS Extension, HS 994.

Howard TG, Gurevitch J, Brown K, Prank W (2000).The differential influence of site and soil characteristics on Invasibility of Forest Communities.The Ecological Society of America $85^{\text {th }}$ Annual Meeting.Ecological Society of America, Washington DC.

Hoyt P, Bradfield R (1962). Effect of varying leaf area defoliation and density on dry matter production of corn. Agronomy Journal 54:523-525.

Imeokpara PO, Okusanya BA (1994). Relative effectiveness economics of cultural and medicinal weed control methods in low land rice in southern guinea savanna of Nigeria. Nigerian Journal of Weed Science 10:35-47.

Liu DL, Lovett JV (1993). Biologically active secondary metabolites of barley. II.Phytotoxicity of barley allelochemicals. Journal of Chemical Ecology 19(10):22312244.

Lordbanju OT (1991). Studies on Mexican sunflower (Tithonia diversifolia (Hemsl.). A Gray in Southwestern Nigeria. Unpublished M.Sc. Dissertation of the University of Ibadan, Ibadan.

Mo MH, Ma HM, Xiao QF (2004). Study of allelopathic effect of ethanol on soluble extract of Lactarius hatsudake on Oryza sativa and Echinoloa crusgall. Acta Ecological Sinica 24:2951-2954.

Moughalu JI, Chuba DK (2005). Seed germination and reproductive strategies of Tithonia diversifolia and Tithonia rotundifolia. Applied Ecology and environmental Research $3(1): 39-46$.

Nasir H, Igbal Z, Araya H, Ominami H Fujii Y (2005). Growth promoting attribute of Stevia rebaudiana. Paper presented at 
70 the Fourth World Congress in Allelopathy. $21^{\text {st }}-26^{\text {th }}$ August 2005.

Otusanya OO, Adelusi AA, Ilori JA (2007). Phytotoxicity effect of Tithonia diversifolia on germination and growth of rice. Research Journal of Botany 2(1):23-32.

Oyerinde RO, Otusanya OO, Akpor OB (2009). Allellopathic effect of Tithonia diversifolia on the germination, growth and chlorophyll contents of maize (Zea mays L.) Scientific research and Essay Vol 4 (12):1553-1558.

Patterson DT (1981) Effects of Allelopathic Chemicals on Growth and Physiological Responses of Soybean GlycineMax Cultivar Tracy. Weed Science 29:53-59.

Rice EL (1984). Allelopathy. Second Edition. Academic Press Inc., Orlando.

Samuel OP, Jennifer AR, Keith C (2005). Invasive Plant can Inhibit Native Tree Seedling: Testing Potential Allelopathic Mechanism. Plant Ecology 18:153-165
Taiwo LB, Makinde JO (2005). Influence of water extract of Mexican Sunflower on growth of Cowpea. African Journal of Biotechnology 4(41):355-360

Tongman S, Kobayashi K, Usui K (1998). Allelopathic activity of Mexican Sunflower (Tithonia diversifolia) in soil. Weed Science 46:432-437.

Yang CM, Lee CN, Chov CH (2002). Allelopathic phenolics and chlorophyll accumulation, effect of three allelopathic phenolics on chlorophyll accumulation of rice [Oryza sativa] seedlings: inhibition of supply orientation. Botanical Bulletin of Academia Sinica 43:299-304.

Wu SH, Wang HH (2005).Potential Asteraceae Invaders in Taiwan: Insights from the Flora and Herbarium Records of Casual and Naturalized Alien Species. Taiwania 50(1):6270. 